\title{
Hydrochemical studies in Lake Baikal: history and nowadays
}

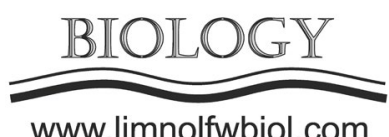

www.limnolfwbiol.com

\author{
Khodzher T.V.*, Domysheva V.M., Sorokovikova L.M., Tomberg I.V., Sakirko M.V.
}

Limnological Institute, Siberian Branch of the Russian Academy of Sciences, Ulan-Batorskaya Str., 3, Irkutsk, 664033, Russia

\begin{abstract}
This work is about the history and the main stages of the hydrochemical studies in Lake Baikal for the last 90 years. The first studies of Baikal water chemistry, including its deep-water zone, had been carried out at the late 1920s under the guidance of G. Yu. Vereshchagin. At the same time, the guide that was used during many years by chemical hydrologists for water chemistry analyses not only on Baikal had been developed. The long-term hydrochemical research of 1950s-1960s gave data on background concentrations of chemical components both in the lake and in its tributaries. The nowadays data evidence that the content of major ions in the deep-water zone of Lake Baikal is constant. It is found that the temporal and space changes of nutrients concentrations in the pelagic zone of the lake depend mainly on phytoplankton growth, whereas the current increase of nutrients concentrations in the littoral is mainly induced by human activities and the development of tourism.

It is found that the Selenga River, the largest tributary of the lake, undergoes the highest anthropogenic load. The pollutants, which enter the river in Mongolia, affect the content of major ions, nutrients and organic matter on the territory of Russia up to the mouth; more pollutants are added by Russian local wastewater sources. Amid the ongoing low water levels and increased anthropogenic load, the annual average concentrations of mineral phosphorous in the Selenga River show a trend to decline, whilst the content of phosphorous organic compounds increases. The efflux of mineral and total phosphorous by the Selenga is governed by changes of the water runoff. Changes in chemical composition of low-mineralized rivers of South Baikal (Khara-Murin and Pereemnaya) whose water catchment areas were affected for many years by emission of the Baikal Pulp and Paper Mill and by transfer of pollutants from the industrial complexes of Pribaikalye are registered.
\end{abstract}

Keywords: Lake Baikal, chemical composition, major ions, nitrogen, phosphorus, tributaries, biogenic elements

\section{Hydrochemical studies in Lake Baikal and its tributaries in 1926-2000.}

In terms of water chemistry, Lake Baikal is one of the most well studied lakes of the world. The hydrochemical studies of the lake and its tributaries began in 1925 with the organization of the Baikal expedition of the USSR Academy of Sciences. In 1926, A.G. Frank-Kamenetsky first obtained the data on the chemical composition of Baikal deep water from a depth of $1000 \mathrm{~m}$. In 1927, G.Yu. Vereshchagin, director of Baikal Limnological Station (BLS) of the USSR Academy of Sciences, characterized the water of the deep zone in South Baikal as low mineralized, with content of major ions, such as bicarbonate, calcium, sulfate and magnesium, less than $100 \mathrm{mg} / \mathrm{L}$. Other components, such as oxygen, free carbon dioxide, silicon, and organic matter, changed in the abyssal zone (Vereshchagin, 1927). At the same time, T.B. Forsh started studying the lake tributaries and obtained the most significant results. The chemical composition of the tributaries was compared with geological structure of their basins; there was an increase in mineralization of river waters during wintertime. G.Yu. Vereshchagin and I.P. Sidorychev carried out more detailed investigations of the Selenga River, in which they paid a special attention to its gas regime (Vereshchagin and Sidorychev, 1929). In 1930, G.Yu. Vereshchagin headed the development, publication and translation into foreign languages of a manual on standard chemical methods of field water analyses, which for many years served as a handbook for chemical hydrologists (Vereshchagin, 1933). Unfortunately, many materials on the Baikal water chemistry remained unprocessed and then were lost.

The next stage in the hydrochemical studies began in 1948, when a new director of BLS chemical hydrologist V.A. Tolmachyov initiated studies of water chemistry at a longitudinal section across the lake, monitoring observations near the Listvyanka settlement, studies of the largest bays and tributaries of Lake Baikal, as well as the Angara River. The studies carried 
out on the instructions of government bodies ahead of designing the Irkutsk Hydropower Station (Tolmachyov, 1957).

In the late 1940 s - early 1950 s, the chemical hydrologists I.V. Glazunov and K.K. Votintsev started working in BLS. The publications by I.V. Glazunov were notable for versatility, singularity of reasoning, thorough collection and processing of materials. He collected data on water chemistry of the Listvennichny Bay, the Angara River head and the main tributaries of the lake. He first found an inflow of the Selenga waters distributed in 25-50 m layer in the area of the Listvennichny Bay, summarized results of investigations of the hydrological regime of the Angara River, and quantified the chemical flow from Lake Baikal (Glazunov, 1963). One of the first publications by K.K. Votintsev was the study of the Baikal ice phase. Based on the materials collected during 1948-1955, he wrote the monograph "Water chemistry of Lake Baikal" (Votintsev, 1961), where he examined in details the chemical composition of water, vertical distribution, seasonal and daily fluctuations of specific components, gave a general hydrochemical characteristic of open Baikal and isolated areas of the lake (bays, coves). He also briefly described the composition of bottom sediments and interstitial waters, discussed hydrochemical zonal distribution of the lake water masses, examined the water chemistry of the largest tributaries and the chemical composition of precipitations, and quantified the chemical balance of Lake Baikal. Great attention was paid to the dynamics of nutrients, silicon migration pathways, cycles of organic matter and oxygen. This book was for decades and remains nowadays a handbook for those who studies Baikal.

In the late 1950s - early 1960s, A.I. Meshcheryakova, N.V. Verbolova, T.P. Kozhevnikova, and L.A. Gorbunova continued hydrochemical investigations. Their hands sampled tons of water and carried out thousands of analyses that became a basis for characterization of the hydrochemical regime of the whole lake up to 300- $m$ depth and the abyssal zone of South Baikal up to the depth $1400 \mathrm{~m}$ (Votintsev et al., 1963). They processed and summarized all materials on water chemistry of Baikal tributaries available at BLS. This work resulted in publishing the monograph "Water chemistry of rivers of the Baikal catchment area" (Votintsev et al., 1965). This monograph characterizes the water chemistry of 250 tributaries of the lake and of a few rivers of its catchment area. It describes in details the hydrochemical regime of 18 main tributaries that were regularly monitored for many years. All the tributaries were divided into 5 groups and referred to 5 types according to their water composition and hydrochemical regime. Until now, this book has not lost its importance being the integral reference book on the water chemistry of surface waters in the region. These materials were used as a basis for hydrochemical mapping of the Baikal catchment area and for the map of hydrochemical facies (Atlas of the Irkutsk Region, 1962). The design and construction of the Baikalsk Pulp and Paper Mill triggered systematic investigations of the southern end of Lake Baikal and its tributaries in the area in 1960-1963. The construction of the mill also initiated the studies of possible impact of its effluents on the composition of Baikal water. This became one of the main research directions for many years, and when the mill began operating, they took form of regular observations.

Since 1962, synchronous limnological surveys on 12 transversal profiles across the entire Baikal water area were carried out for several years. They were carried out simultaneously on six vessels, and this allowed getting an "instant picture" of the whole state of Baikal. The results were included to the report of the National Program of the USSR, which was performed within the framework of the International Biological Program. At the same time, the data on annual integrated monitoring at the network of regular stations in the Selenga area, the most important fishing area of Baikal, were summarized (Votintsev and Glazunove, 1963). In 19711974, these studies were continued (Bogdanov, 1972) and included the Selenga shallows, as well as the sors (lagoons) Proval, Istok and Posolsk, where changes in hydrochemical composition associated with the rise of water level in Baikal after the construction of the Irkutsk Hydropower Station Dam were recorded. The construction of the Baikal-Amur Main Line (BAM) and its influence on the water chemistry of North Baikal gave rise to investigations of the northern end of Lake Baikal and its tributaries. The comprehensive long-term studies at the Baikal portion of BAM allowed developing recommendations for reducing negative effects of the construction activities on the water quality in the basin of the Upper Angara River, which is the main tributary of North Baikal (Bogdanov, 1978).

In the early 1960s, new fields of research appeared in the water chemistry: chemistry of interstitial water, exchange processes at the water-bottom interface, processes of early diagenesis in sediments, and biogeochemical migration of individual chemical elements in the Baikal ecosystem, which were headed by I.B. Mizandrontsev. He and his team studied the composition of bottom sediments, their physical and chemical properties, processes of consolidation and transformation, as well as diagenetic transformations of iron and manganese. They gave a theoretical description of the matter exchange between the water and bottom in the oxygen-depleted hypolimnion of some water bodies. They made a theoretical analysis of the influence of sedimentation conditions on the physicochemical environment and functioning of the benthic organisms (Mizandrontsev, 1990).

In 1965, E.N. Tarasova headed the studies of organic matter: the direct measurements of organic carbon, COD, organic nitrogen and phosphorous concentrations were introduced both in lake water and in the suspensions of the water column (Tarasova, 1975). Developing studies of balance and cycling of organic matter in Baikal K.K. Votintsev quantified the role of organic matter in the biological productivity of the lake. In this regard, he proposed a general quantitative scheme for the bioenergetic transformation of organic matter in food chain of the ecosystem in the pelagic zone of the lake (Votintsev, 1971; Votintsev et al., 
1975). Since 1976, the studies have been resumed on the chemical composition of precipitation and eolian particles falling onto the surface of the lake (Votintsev and Khodzher, 1981). These studies allowed clarifying the role of the atmospheric component in the chemical balance, assessing the changes since 1950s, indicating local atmospheric pollution, and detecting its sources (Khodzher, 1988). In 1975-76, the draft of the National Baikal Water Quality Standard was developed. Mathematical processing of more than 700 complete analyses of the lake water yielded average values and confidence intervals for individual chemical components and confirmed their homogenous distribution both throughout the lake water area and by depths (Votintsev and Mizandrontsev, 1981).

The study of the formation of the hydrochemical regime of the Angara River and the Angaro-Yenisei basinwas one of the important research areas of the Laboratory of Hydrochemistry and Atmosphere Chemistry. The most extensive studies concerning forecast and formation of the hydrochemical regime in the Bratsk, Ust-Ilimsk, Sayano-Shushensk and Kureisk reservoirs were carried out in 1980-1990. The studies at the Nizhyaya Tunguska and the Lower Yenisei Rivers served as a basis for predicting the water quality of the intended Turukhansk Reservoir. The data obtained during these studies in cooperation with other institutes of the Siberian Branch of the Academy of Sciences of the USSR for the first time in Soviet limnology prevented the construction of this hydroelectric power plant.

From the beginning of the 90s, a new stage of hydrochemical research began, a distinctive feature of which was the development and implementation of new methods of analysis, careful quality control of the data obtained, and close cooperation with foreign scientists. Thus, in the late 80 s and early 90 s, within two international expeditions there were studies of the major ions and trace elements in the pelagic zone of the lake from the surface to the bottom along all three basins. The results of these studies were published in the journal Limnology and Oceanography (Falkner et al., 1991; 1997), and they once again confirmed the conclusions of the previous long-term studies that the concentrations of major ions in different basins and at different depths of open Baikal are the same. M.A. Grachev summarized the results of international studies at Lake Baikal performed in the 80s and 90s were in the monograph "The current state of ecological system of Lake Baikal" (Grachev, 2002), which provides an overview of the main data on the chemical composition of Baikal water that had been obtained by Russian and foreign researchers.

\section{Hydrochemical investigations of Lake Baikal and its tributaries in 2000-2017.}

Since the beginning of the 2000s, the main hydrochemical studies have been expanded both by objects and by territory studied and are currently being carried out in the following areas: Water chemistry of Lake Baikal and its tributaries under climate change and anthropogenic load; The chemical composition of the atmosphere in the Baikal Natural Territory, including analysis of the composition of gas impurities, aerosols, precipitation and snow cover; Geochemical processes at the water-air and water-bottom interfaces, chemical composition of Baikal pore waters; Hydrochemical regime and water quality forecast of Siberian reservoirs.

The measurements carried out at present using the methods developed in the Institute have high accuracy: up to $15 \%$ for biogenic elements and 5-7\% for major ions (Baram et al., 1999; Vereshchagin et al., 2000). Comparison of the 1940 - 1960 data with modern ones showed that the results of analyses performed by classical methods of the early 20th century are comparable with the data obtained today. Over the past 18 years, Russian and international qualification comparative tests monitor the results of annual chemical water analyses. According to the international qualification comparative tests, the deviations of the analysis results from the true values in general do not exceed 10-15\%, which indicates the reliability of the data on the hydrochemistry of natural waters (Khodzher et al., 2004).

Currently, the study of the chemical composition of Baikal waters and its tributaries remains the urgent task due to the climate change and the increasing anthropogenic load on the lake ecosystem. Due to the long time of water exchange in Baikal (more than 300 years), the content of major ions in its water column remains constant, without variations by depths and basins. The regular expeditions around Baikal carried out at 20 deep-water stations and 7 cross sections across the lake confirm this feature. Seasonal sampling is performed in the mouths of large tributaries and the littoral zone of the lake. During each expedition, 350-400 water samples are taken. Gas composition and nutrients are analyzed onboard, and macro and microelements are analyzed in the laboratory (Khodzher et al., 2017). Table 1 shows the content of major ions in the pelagic zone of Lake Baikal. It indicates that the water composition in the abyssal zone of Lake Baikal currently remains constant. Statistical processing of the data showed that the variations in alkalinity and concentration of sodium, calcium, magnesium, and sulfate ions in Baikal water do not exceed $\pm 5 \%$. The statistical error is significantly more, up to $10 \%$, in determining $\mathrm{K}^{+}$and $\mathrm{Cl}^{-}$, which concentrations are low (Grachev, 2004).

In contrast to the major ions, the content of oxygen and biogenic elements in the Baikal water has an obvious vertical stratification and seasonal dynamics due to biological processes and the dynamics of the lake water masses. During 2014-2018, more than 1500 individual water samples at 20 deep-water stations from 10-14 depth horizons at each station were taken and analyzed for silicon and various forms of phosphorus and nitrogen. In spring, the maximum concentration gradient of mineral phosphorus is observed in the upper $200 \mathrm{~m}$ layer in the southern and central basin, and in the upper $100 \mathrm{~m}$ layer in the northern part of the lake due to its later ice-breakup (Fig. 1). The content of mineral phosphorus increases with depth and in the near-bottom area is $15-16 \mu \mathrm{g} / \mathrm{L}$ in the south and north basins, and 18-20 $\mu \mathrm{g} / \mathrm{L}$ in the central basin of the lake. Interannual variations of the average concentration of 
Table 1. Concentrations and the sum of major ions in the pelagic area of Lake Baikal measured in different years, mg/L

\begin{tabular}{|l|c|c|c|c|c|c|c|c|}
\hline Authors & $\mathbf{C a}^{2+}$ & $\mathbf{M g}^{2+}$ & $\mathbf{N a}^{+}$ & $\mathbf{K}^{+}$ & $\mathbf{H C O}_{3}^{-}$ & $\mathrm{Cl}^{-}$ & $\mathbf{S O}_{4}{ }^{2-}$ & $\Sigma_{\mathrm{i}}$ \\
\hline Vereshchagin, 1947 & 15.2 & 4.1 & 3.9 & 2.3 & 63.6 & 0.7 & 5.0 & 94.8 \\
Votintsev, 1961 & 15.2 & 3.1 & 3.8 & 2.0 & 66.5 & 0.6 & 5.2 & 96.4 \\
Falkner et al., 1991 & 16.1 & 3.1 & 3.6 & 0.9 & 66.7 & 0.4 & 5.5 & 96.3 \\
Grachev et al., 2004 & 16.4 & 3.0 & 3.3 & 1.0 & 66.6 & 0.4 & 5.2 & 95.9 \\
LIN SB RAS data, 2015-2016 & 16.0 & 3.1 & 3.4 & 1.0 & 64.9 & 0.5 & 5.4 & 94.3 \\
\hline
\end{tabular}

mineral phosphorus throughout the water column, except for the upper $100 \mathrm{~m}$ layer, are insignificant and do not exceed $8 \%$ of the average value in each basin. In the upper $100 \mathrm{~m}$ layer of the southern basin, these variations are higher (up to $30 \%$ ) due to the different development intensity of spring phytoplankton.

The distribution of total phosphorus is similar to mineral. The content of organic phosphorus in the deep-water area of the lake is $2-3 \%$, and in the upper $100 \mathrm{~m}$ layer it reaches $20-30 \%$.

Mineral forms of nitrogen in Baikal are mainly represented by nitrate. The seasonal dynamics and vertical distribution of nitrate are similar to those of mineral phosphorous, with minimum values in the surface layer and maximum values in the near-bottom waters (Fig. 2). The concentration of nitrates in the near-bottom water reaches $0.16 \mathrm{mg} \mathrm{N} / \mathrm{L}$; in the upper water layer it varies from 0.01 to $0.07 \mathrm{mg} \mathrm{N} / \mathrm{L}$ depending on seasons. Interannual variations of the nitrate concentrations throughout the water column are also insignificant and do not exceed $8 \%$.

Small amounts of ammonium and nitrite nitrogen are found only in in the upper water layers, mainly, at the end of the algae vegetation period, as well as in the bottom horizons. The littoral zone of the lake usually contains ammonium and nitrite nitrogen, but the content of these forms of nitrogen is insignificant.

At present, there is a problem of pollution in the Baikal littoral zone driven by discharge of insufficiently treated wastewaters from towns and settlements located on the coast, as well as increase in tourist load and vessels, which negatively affect the ecosystem of the lake. Climate change aggravate negative consequences affecting the water regime of the lake and its catchment area, duration of the ice period, temperature of the upper water layers, and productivity processes. Over the past decade, detailed seasonal studies of the dynamics of biogenic elements and gas composition in the Baikal littoral zone were conducted in the area of South Baikal (Golobokova et al., 2009; Domysheva et al., 2010; 2012; 2013; Sakirko et al., 2015).

The most detailed seasonal studies in the littoral zone were conducted near Bolshiye Koty (western shore of South Baikal). Figure 3 shows the results of measurements of the surface and near-bottom water performed each 3 hours within 24 hours in separate cycles during 2013-2015. The content of biogenic elements clearly shows the annual variation with a maximum in the winter and a minimum in the summer.

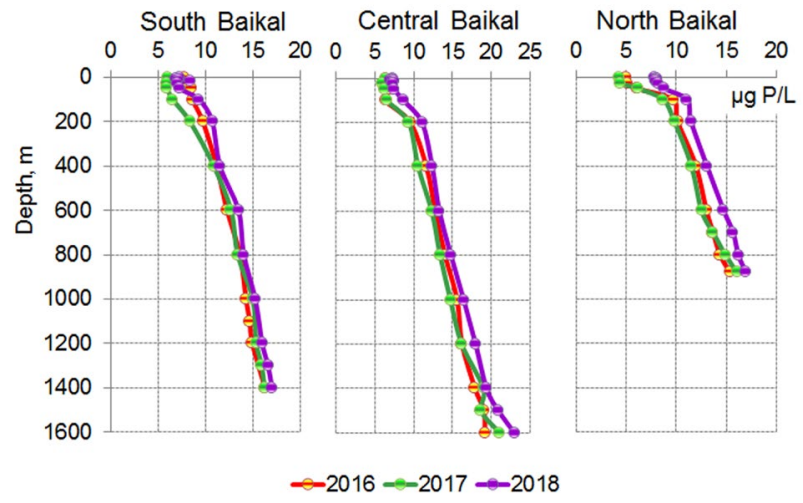

Fig. 1. Mean mineral phosphorus concentration in the individual basins of Lake Baikal in May-June 2014-2016.

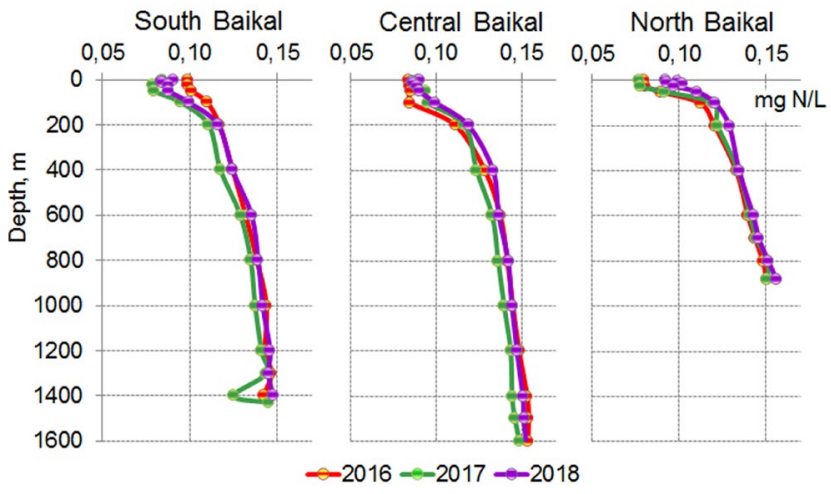

Fig. 2. Mean nitrate concentration in the individual basins of Lake Baikal in May-June 2014-2016.

During intensive development of phytoplankton, there were significant diurnal changes in $\mathrm{pH}$ values and saturation of water with oxygen.

In addition, in June and September 2014-2016 the investigations were carried out in the littoral zone of more than 30 permanent stations around the lake. Analysis of the results indicated that in June the concentrations of biogenic elements and organic matter in the littoral water were significantly higher than in September due to the intra-annual dynamics of the components concentrations in Baikal water and the coastal runoff in spring and summer, when the lake level rises. During the observations, the phosphate concentrations varied from 2 to $11 \mu \mathrm{g}$ P/L in June, and in September 

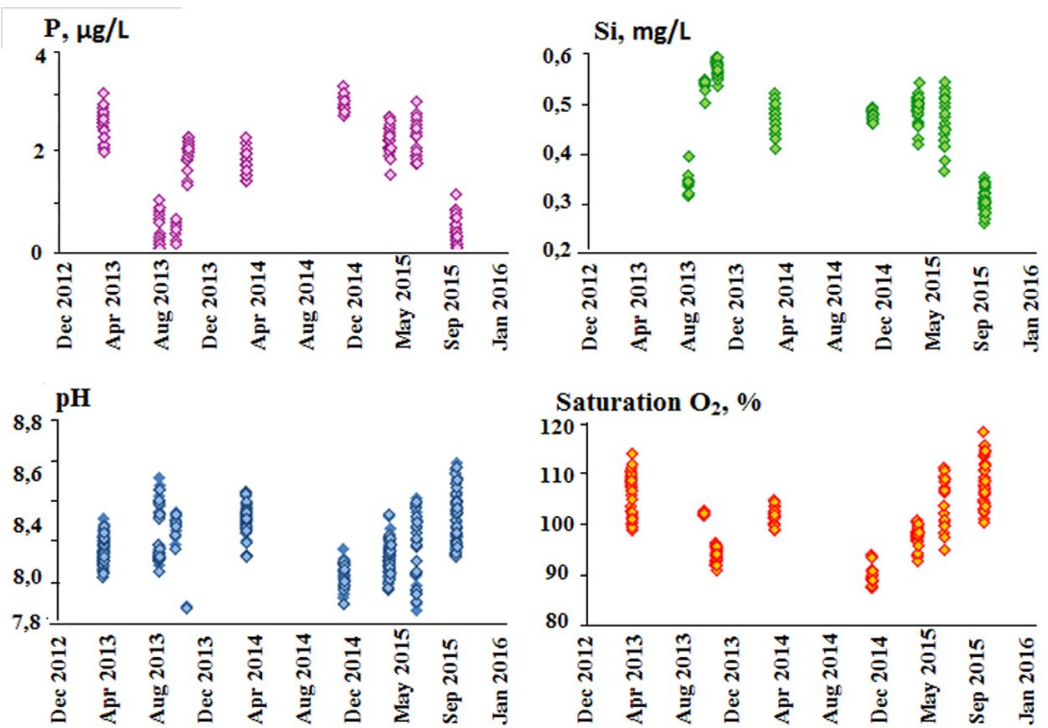

Fig. 3. Concentrations of mineral phosphorus, silicon, $\mathrm{pH}$ value and oxygen saturation in the littoral zone of South Baikal (Bolshye Koty), 2013-2015.

they did not exceeded $7 \mu \mathrm{g}$ P/L. The total content of mineral nitrogen $\left(\mathrm{NO}_{2}{ }^{-}+\mathrm{NO}_{3}{ }^{-}+\mathrm{NH}_{4}{ }^{+}\right)$varied from 0.01 to $0.3 \mathrm{mg} \mathrm{N} / \mathrm{L}$. To determine reference concentrations of biogenic elements in the littoral water of Baikal, 63 water samples at 23 stations located outside the zone of influence of permanent settlements and towns were collected and analyzed. The results showed that the phosphate concentrations were in the range 0-6 $\mu \mathrm{g} \mathrm{P} / \mathrm{L}$ in $90 \%$ of the analyzed samples; the content of mineral nitrogen did not exceed $0.05 \mathrm{mg} \mathrm{N} / \mathrm{L}$ in $89 \%$ of the samples (Fig. 4).

The determination of the $\mathrm{N}$ and $\mathrm{P}$ reference concentrations allowed assessing the situation in the littoral zone under anthropogenic pressure. Despite the high phosphate concentrations in some seasons, their average values did not exceed reference values during the period of observations in these areas. At the same time, the average concentrations of mineral nitrogen can be 2.5-3 times higher than reference values (Fig. 5).

Notably, in the coastal water near the settlements of Khuzhir, Maksimikha, Sakhyurta, Severobaikalsk, Kultuk and others, there were rather high concentrations of ammonium nitrogen (up to $0.04 \mathrm{mg} \mathrm{N} / \mathrm{L}$ ). In certain periods, ammonium nitrogen dominated nitrates, which is not typical of well-aerated Baikal waters with a high $\mathrm{pH}$ value.

One of the most important abiotic factors that determine the chemical composition of Baikal water is the river runoff. The waters of most rivers as well as those of the lake by relative content of major ions correspond to the bicarbonate class of the calcium group. The main regularities and the first most complete data on the formation of chemical water composition of the tributaries were obtained in 1940-1960 (Bochkarev, 1956; Votintsev et al., 1965). These data characterize the natural regional chemical composition of river waters and can serve as a reference in assessing its changes caused by the development of industry and agriculture in river basins. In the late 1990s, the concentration of sulfate and its runoff into the lake with the waters of the Selenga River, the main tributary of the lake, a
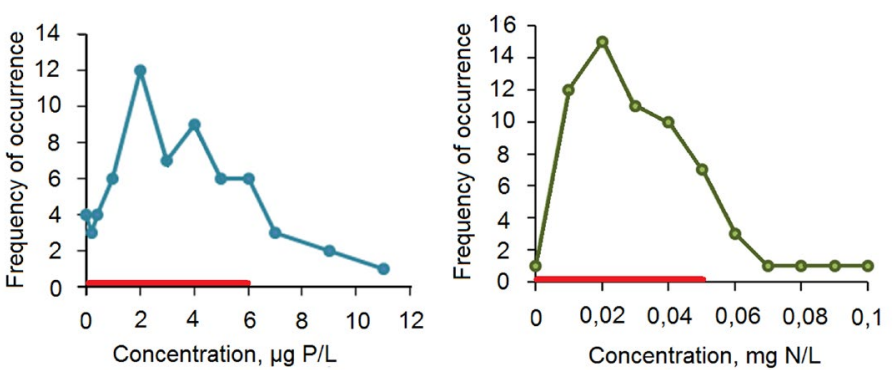

Fig. 4. Variation curves reflecting the distribution of phosphate (a) and mineral nitrogen (b) concentrations in the littoral water samples.

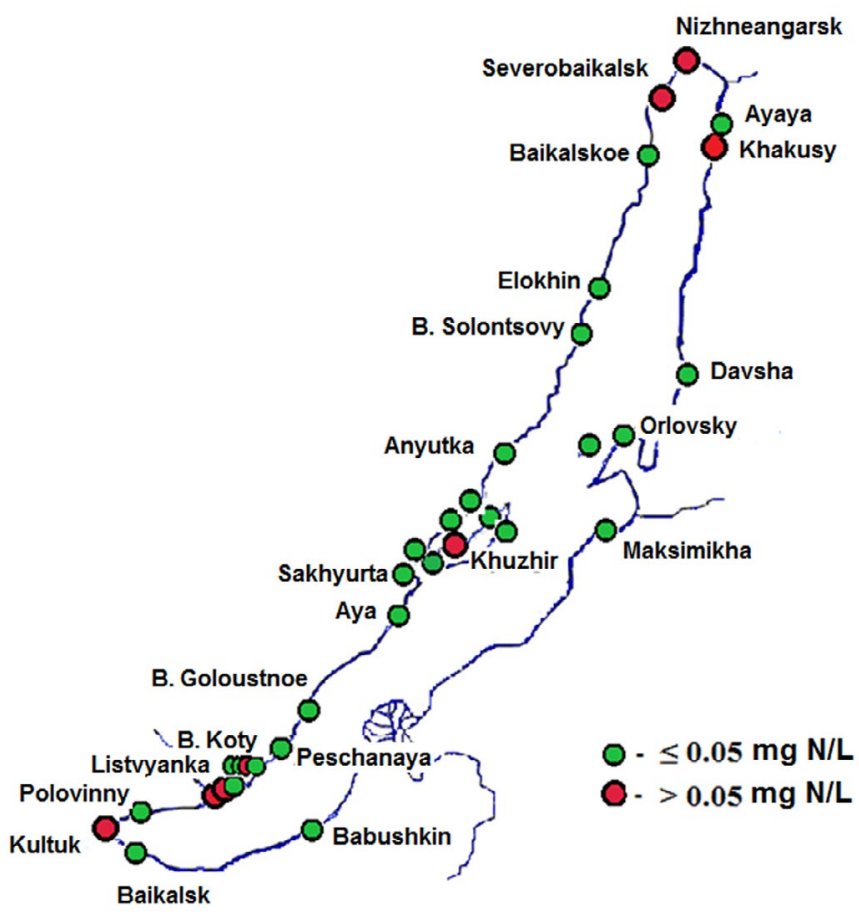

Fig. 5. Mean mineral nitrogen concentrations in the coastal water of Lake Baikal, 2014-2016, mg/L 
already twice increased compared to Votintsev et al. (1965), nitrate nitrogen - by $57 \%$, mineral phosphorus - by 42\% (Sorokovikova et al., 2000a; 2000b). In the past two decades, the chemical composition and hydrochemical regime of the rivers in the Baikal catchment area are formed under climate change, prolonged low water level and increased anthropogenic stress. The Selenga River experiences the highest technogenic load due to intensification of economic activity both in the Russian and Mongolian parts of the river. In the 1990s, the sulfate concentrations at the Naushki settlement bordering with Mongolia remained at the reference levels of 7.5-10.5 mg/L (Sorokovikova et al., 1995); by 2010 they increased to $10.6-16.4 \mathrm{mg} / \mathrm{L}$ (Tomberg et al., 2010; Sorokovikova et al., 2013), and in 2018 they were $17.1-21.7 \mathrm{mg} / \mathrm{L}$. The increase in anthropogenic load under the low water conditions also caused an increase in concentrations of biogenic elements in the water of the Selenga River and their runoff into the lake.

In 2010-2016, the average runoff of total phosphorus into the lake increased and was 1770 tons/ year. At the same time, the minimum runoff (670 tons) occurred in an abnormally low water level in 2015, whereas the maximum one (3200 tons) - in 2013 (Fig. 6 ). The average runoff of mineral phosphorus during this period reduced to 206 tons/year, i.e. 34\% of the corresponding value of the 1990s (Sorokovikova et al., 2000b). Obviously, the structure of phosphorus intake into the lake changed: the runoff of its mineral compounds decreased, while the runoff of its organic compounds increased. The excess of the runoff of organic phosphorus over mineral phosphorus in the low-water year was 769 tons, in the high-water year - 2886 tons, whereas in 1983-1984 the excess was at the level of 120 tons (Tarasova and Meshcheryakova, 1992).

The concentrations of the major ions and their total content in the Barguzin and Upper Angara rivers and their tributaries changed slightly in the perennial aspect, except for sulfate concentration, which increased in the Barguzin River (Drucker et al., 1997; Sorokovova et al., 2015). The seasonal dynamics of concentrations of biogenic elements in the rivers not subjected to pollution by sewage water is mainly determined by changes in water runoff and the intensity of plankton development. The smallest concentrations of biogenic elements were determined in the water of the Upper Angara River due to the low development of its basin.

The rivers of South Baikal (Snezhnaya, Utulik, Khara-Murin, Solzan, Pereyomnaya) are characterized by low mineralization (14-115 mg/L) due to the significant heights of their basins and higher moisture. For fifty years, the catchment areas of these rivers were under influence of emissions from the Baikalsk Pulp and Paper Mill and the regional transfer of pollutants from the Angaro-Cheremkhovsky industrial complex, which affected the chemical composition of precipitation and, consequently, the composition of river waters (Sorokovikova et al., 2004). Acidic precipitation (4.7$5.3 \mathrm{pH}$ ) with a high content of nitrogen and sulfur compounds made the extremely low mineralized waters of

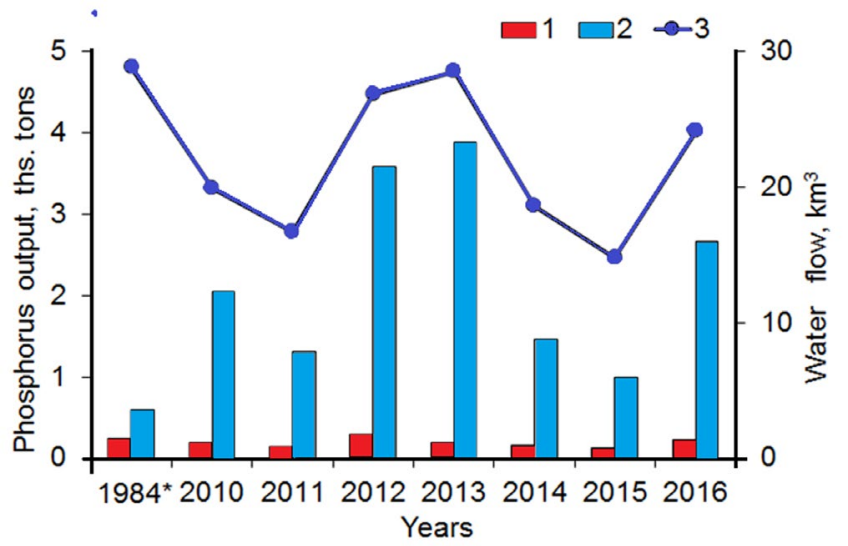

Fig. 6. Changes in the mineral (1) and total (2) phosphorus runoff by the Selenga River in years with different water content (3)

the Khara-Murin and Pereemnaya rivers less resistant to acidification. The waters of these rivers correspond to the sulfate class of calcium group for a significant part of the year. The waters of the Solzan, Utulik and Snezhnaya rivers have a higher buffer capacity; their composition remains stable and corresponds to the bicarbonate class of calcium group (Obolkin et al., 2016; Tomberg et al., 2016).

Increasing economic and tourist activities in Listvyanka (the western shore of South Baikal), particularly, the construction of hotels and the discharge of untreated wastewater, led to an increase in the nitrogen and phosphorus content in the estuaries of the Krestovka River, as well as in Kamenushka, Malaya Cheremshanka and Bolshaya Cheremshanka streams flowing into Lake Baikal (Chebunina et al., 2018). In recent years, Listvyanka has been experiencing an "environmental crisis" - the death of endemic plant and animal species and their replacement by widespread species, one of the reasons for which may be an increase in biogenic elements in the Baikal littoral zone (Kravtsova et al., 2012; 2014; Khanaev et al., 2018).

\section{Conclusion}

Long-term hydrochemical studies conducted in the Limnological Institute and analysis of recent years (2014-2017) showed that the Baikal deep waters are low mineralized and belong to the bicarbonate class of calcium group. The content of the major ions (calcium, magnesium, sodium, potassium, bicarbonates, sulfates, and chlorides) is constant throughout the water column of the abyssal zone of the lake. There is small number of biogenic elements (nitrogen, phosphorus, and silica), and their concentrations increase with depth. The temporal and spatial dynamics of biogenic elements in the trophogenic layer is due to the intensity of phytoplankton development.

Though the pelagic zone of the lake remains stable, the problems of local pollution of the coastal waters of the aquatic area with biogenic elements, organic matter coming along with the tributaries from settlements, tourist complexes located on the coast of the lake, and the number of ships constantly increasing remain the main thread for the ecosystem of the lake. 
Changes in the littoral zone of the lake increase under climate warming.

In the 1970-1980s, the development of industry and agriculture in the basin of the main tributaries of the lake caused an increase in anthropogenic load and decrease in the water quality. In recent years, there is a high content of major ions in the waters of the Selenga River due to a decrease in the river water level and an increase in the groundwater supply. Concentrations and the runoff of mineral phosphorus by the river into the lake decreased, whilst the intake of total phosphorus, organic matter and phytoplankton biomass increased. The content of total phosphorus in certain periods reaches the values characteristic of eutrophic waters. The influence of small tributaries on the chemical composition of the chemical composition in the lake water is insignificant and is found only in the estuaries.

Hydrochemical studies of the Baikal water and its tributaries performed in the monitoring regime with the modern analytical equipment and by high-precision analytical methods provide reliable results on the state of the lake ecosystem. This work is extremely important and will be continued in order to develop a strategy to protect the lake from pollution.

\section{Acknowledgments}

The study was carried out within the Projects Nos. 0345-2016-0008 (AAAA-A16-116122110065-4) and 0345-2016-0009 (AAAA-A16-116122110067-8).

\section{References}

Atlas of the Irkutsk Region. 1962. Moscow-Irkutsk. (in Russian)

Baram G.I., Vereshchagin A.L., Golobokova L.P. 1999. Microcolumn high-performance liquid chromatography with UV detection for the determination of anions in the environmental materials. Journal of Analytical Chemistry 54: 962965.

Bochkarev N.F. Hydrochemistry of the Selenga River. 1958. Trudy IGU. Seriya geograficheskaya [Proceedings Irkutsk State University] 24: 143-163. (in Russian)

Bogdanov V.T. 1972. Distribution of the Selenga waters of the lake Baikal by hydrochemical data. In: Conference on Status and prospects of development of studies of pollution and self-purification of surface waters, Novocherkassk, pp. 22-23.

Bogdanov V.T. 1978. Formation of the hydrochemical regime of North Baikal. Novosibirsk: Nauka. (in Russian)

Chebunina N.S., Onischuk N.A., Netsvetaeva O.G. et al. 2018. Dynamics of the content of mineral forms of nitrogen in watercourses and precipitation of Listvyanka (South Baikal) Russia. Izvestiya IGU. Seriya "Nauki o zemle" [The Bulletin of Irkutsk State University] 24: 124-139. DOI: 10.26516/20733402.2018.24.3 (in Russian)

Domysheva V.M., Sakirko M.V., Pestunov D.A. et al. 2010 Seasonal trend of $\mathrm{CO}_{2}$ gas exchange in the system "atmosphere-water" in the littoral area of Lake Baikal. 1. Hydrological spring. Optika atmosfery i okeana [Atmospheric and Oceanic Optics] 23: 1067-1074. (in Russian)

Domysheva V.M., Sakirko M.V., Pestunov D.A. et al. 2012. Seasonal trend of $\mathrm{CO}_{2}$ gas exchange in the system "atmosphere-water" in the littoral area of Lake Baikal. 3. Autumn. Optika atmosfery i okeana [Atmospheric and Oceanic Optics] 25: 826-832. (in Russian)

Domysheva V.M., Panchenko M.V., Pestunov D.A. et al. 2013. Air-water carbon dioxide exchange in the littoral zone of Lake Baikal (Ice-Free Period). International Journal of Geosciences 4: 1339-1345. DOI: 10.4236/ijg.2013.410130

Drucker V.V., Sorokovikova L.M., Sinyukovich V.N. et al. 1997. Water quality of the Barguzin River under recent conditions, Russia. Geografiya i prirodnye resursy [Geography and Natural Resources] 4: 72-78. (in Russian)

Falkner K.K., Measures C.I., Herbelin S.E. et al. 1991. The major and minor element geochemistry of Lake Baikal. Limnology and Oceanography 36: 413-423. DOI: 10.4319/ 10.1991.36.3.0413

Falkner K.K., Church M., Measures C.I. et al. 1997. Minor and trace element chemistry of Lake Baikal, its tributaries and surrounding hot springs. Limnology and Oceanography 42: 329-345. DOI: 10.4319/lo.1997.42.2.0329

Glazunov I.V. 1963. Hydrochemical regime and chemical runoff of the Angara River. Gidrokhimicheskiye issledovaniya ozera Baikal. Trudy limnologicheskogo instituta. [Hydrochemical studies of Lake Baikal. Proceedings of Limnological Institute] 3: 57-94. (in Russian)

Golobokova L.P., Sakirko M.V., Onischuk N. et al. 2009. Hydrochemical characteristics of the waters of the northwestern littoral of the southern Baikal. In: Timoshkin O.A. (Ed.), Index of animal species inhabiting Lake Baikal and its catchment area. Novosibirsk, pp. 760-784. (in Russian)

Grachev M.A. 2002. The current state of ecological system of Lake Baikal. Novosibirsk: SB RAS. (in Russian)

Grachev M.A., Domysheva V.M., Khodzher T.V. et al. 2004. Deep water of Lake Baikal as a standard of fresh water. Khimiya $\mathrm{v}$ interesah ustoichivogo razvitiya [Chemistry for Sustainable Development] 12: 417-429. (in Russian)

Khanaev I.V., Kravtsova L.S., Maikova O.O. et al. 2018. Current state of the sponge fauna (Porifera: Lubomirskiidae) of Lake Baikal: Sponge disease and the problem of conservation of diversity. Journal of Great Lakes Research 44: 77-85. DOI: $10.1016 /$ j.jglr.2017.10.004

Khodzher T.V. 1988. The flow of substances from the atmosphere to the sediments of Lake Baikal. In: 1st regional conference on salt migration in the Central Asian region, pp. 85-86. (in Russian)

Khodzher T.V., Golobokova L.P., Netsvetaeva O.G. et al. 2004. Results of testing of chemical parameters of artificial standard samples of rain and surface fresh waters. Optika atmosfery i okeana [Atmospheric and Oceanic Optics] 17: 478-482. (in Russian)

Khodzher T.V., Domysheva V.M., Sorokovikova L.M. et al. 2017 Current chemical composition of Lake Baikal water. Inland Waters 7: 250-258. DOI: 10.1080/20442041.2017.1329982

Kravtsova L.S., Izhboldina L.A., Khanaev I.V. et al. 2012. Disturbances of the vertical zoning of green algae in the coastal part of the Listvennichnyi gulf of Lake Baikal. Doklady Biological Sciences 447: 350-352. DOI: 10.1134/ S0012496612060026

Kravtsova L.C., Izhboldina L.A., Khanaev I.V. et al. 2014. Nearshore benthic blooms of filamentous green algae in Lake Baikal. Journal of Great Lakes Research 40: 441-448. DOI: 10.1016/j.jglr.2014.02.019

Mizandrontsev I.B. 1990. Chemical processes in the bottom sediments of reservoirs (on the example of Lake Baikal). Novosibirsk: Nauka. (in Russian)

Obolkin V.A., Khodzher T.V., Sorokovikova L.M. et al. 2016. Effect of long-range transport of sulphur and nitrogen oxides from large coal power plants on acidification of river waters in the Baikal region, East Siberia. International Journal of Environmental Studies 73: 452-461. DOI: 10.1080/00207233.2016.1165481

Sakirko M.V., Domysheva V.M., Pestunov D.A. et al. 2015. Concentration of nutrients in the water of Southern Baikal in summer. Proceedings of SPIE 9680: 1-7. DOI:10.1117/12.2205753

Sorokovikova L.M., Sinyukovich V.N., Drucker V.V. et al. 1995. Ecological peculiarities of the Selenga River during flood, Russia. Geografiya i prirodnye resursy [Geography and Natural Resources] 4: 64-71. (in Russian)

Sorokovikova L.M., Sinyukovich V.N., Golobokova L.P. 2000a. Formation of ionic flow of the Selenga River under 
modern conditions, Russia. Water Resources 5: 560-565. Sorokovikova L.M., Khodzher T.V., Sinyukovich V.N. et al. 2000b. Atmospheric and riverine components of the flow of biogenic elements and organic matter into Lake Baikal. In: Minoura K. (Ed.), Lake Baikal. Tokyo: Elsevier Science, pp. 236-246.

Sorokovikova L.M., Netsvetaeva O.G., Tomberg I.V. et al. 2004. Effect of atmospheric precipitation on the chemical composition of river waters in South Baikal. Optika atmosfery i okeana [Atmospheric and Oceanic Optics] 17: 423-427. (in Russian)

Sorokovikova L.M., Popovskaya G.I., Tomberg I.V. et al. 2013. The Selenga River water quality on the border with Mongolia at the beginning of the 21 st century. Russian Meteorology and Hydrology 2: 126-133. DOI: 10.3103/ S1068373913020106

Sorokovikova L.M., Sinyukovich V.N., Tomberg I.V. et al. 2015. Assessing the water quality in the tributary streams of Lake Baikal from chemical parameters . Russia. Geography and Natural Resources 1: 31-39. DOI: 10.1134/ S1875372815010059

Tarasova E.N. 1975. Organic matter in the waters of South Baikal. Novosibirsk: Nauka. (in Russian)

Tarasova Ye.N., Meshcheryakova A.I. 1992. Current state of Lake Baikal hydrochemical regime. Novosibirsk: Nauka. (in Russian)

Tolmachyov V.A. 1957. Some hydrochemical parameters of internal water exchange in Baikal. Doklady Akakdemii Nauk 113: 639-642. (in Russian)

Tomberg I.V., Sorokovikova I.V., Sinyukovich V.N. et al. 2010. Flow of ions in the Selenga River delta under conditions of low water. Meteorologiya i gidrologiya [Meteorology and Hydrology] 12: 87-95. (in Russian)

Tomberg I.V., Sorokovikova L.M., Netsvetaeva O.G. et al. 2016. Chemical composition and tendency of acidification of snow waters and waters of the tributaries of the Southern Baikal, Russia. Optika atmosfery i okeana [Atmospheric and Oceanic Optics] 29: 516-520. (in Russian)

Vereshchagin A.L., Dudinskii V.F., Golobokova L.P. et al. 2000. Determination of UV-absorbing anions in environmental samples by microcolumn high-performance liquid chro- matography. Journal of Analytical Chemistry 55: 1000-1002.

Vereshchagin G.Y. 1927. Hydrochemical observations in South Baikal in the summer of 1926. Doklady AN USSR [Reports of the USSR Academy of Sciences] 20: 327-332. (in Russian)

Vereshchagin G.Yu., Sidorychev I.P. 1929. Some observations of the biology of golomyanka. Doklady AN USSR [Reports of the USSR Academy of Sciences] 5: 125-130. (in Russian)

Vereshchagin G.Yu. 1933. Methods for field hydrochemical investigations and their use in hydrological practice. Moscow: Gidrometeoizdat. (in Russian)

Vereshchagin G.Yu. 1947. Baikal. Irkutsk: Geografgiz. (in Russian)

Votintsev K.K. 1961. Water chemistry of Lake Baikal. Trudy Baikalskoi limnologicheskoi stantsii AN SSSR [Proceedings of the Baikal Limnological Station of the Academy of Sciences of the USSR] 20: 1-311. (in Russian)

Votintsev K.K., Glazunov I.V. 1963. Hydrochemical regime of Lake Baikal in the area of the Listvyanka settlement. Trudy limnologicheskogo instituta [Proceedings of Limnological Institute] 3: 3-56. (in Russian)

Votintsev K.K., Verbolova N.V. Meshcheryakova A.I. 1963. Horizontal distribution of some components in the upper water layer of Lake Baikal. Trudy limnologicheskogo instituta [Proceedings of Limnological Institute] 3: 95-112. (in Russian)

Votintsev K.K., Glazunov I.V., Tolmachyova A.P. 1965. Water chemistry of rivers of the Baikal catchment area. Trudy limnologicheskogo instituta [Proceedings of Limnological Institute] 8: 1-495. (in Russian)

Votintsev K.K. 1971. Bioenergy structure of the pelagial ecosystem of Lake Baikal. Zoologicheskii zhurnal [Russian Journal of Zoology] 50: 165-172. (in Russian)

Votintsev K.K., Meshcheryakova A.I., Popovskaya G.I. 1975. Cycle of organic matter in Lake Baikal. Novosibirsk: Nauka. (in Russian)

Votintsev K.K., Mizandrontsev I.B. 1981. On the draft standard of water quality indicators of Lake Baikal circulation of matter and energy in water bodies. In: 5th All-Union Limnological meeting, pp. 26-28. (in Russian) 